\title{
Legal and Economic Prospects for the Arctic Seaport Developments of the Northern Dimension Partner Countries (Russia and the European Union)
}

\author{
Maksim Y. Zadorin ${ }^{1}\left(\mathbb{D}\right.$, Konstantin S. Zaikov $^{2, *} \mathbb{D}$, Nikita M. Kuprikov $^{3,4} \mathbb{D}^{\mathbb{D}}$ and Mikhail Y. Kuprikov ${ }^{3}$ \\ 1 Department of International Law and Comparative Legal Studies, Northern (Arctic) Federal \\ University (Named after M.V. Lomonosov), 163002 Arkhangelsk, Russia; m.zadorin@narfu.ru \\ 2 Department of Regional Studies, International Relations and Political Sciences, Northern (Arctic) Federal \\ University (Named after M.V. Lomonosov), 163002 Arkhangelsk, Russia \\ 3 Department of Engineering Graphics, Moscow Aviation Institute, National Research University, \\ 125993 Moscow, Russia; nkuprikov@yandex.ru (N.M.K.); mkuprikov@gmail.com (M.Y.K.) \\ 4 Higher School of Cyberphysical Systems and Management, Institute of Computer Science and Technology, \\ Peter the Great Saint Petersburg Polytechnic University, 195220 Saint Petersburg, Russia \\ * Correspondence: k.zaikov@narfu.ru; Tel.: +7-953-2660586
}

Citation: Zadorin, M.Y.; Zaikov, K.S.; Kuprikov, N.M.; Kuprikov, M.Y. Legal and Economic Prospects for the Arctic Seaport Developments of the Northern Dimension Partner Countries (Russia and the European Union). Sustainability 2022, 14, 2373. https://doi.org/10.3390/su14042373

Academic Editor: Jungho Baek

Received: 31 December 2021

Accepted: 14 February 2022

Published: 18 February 2022

Publisher's Note: MDPI stays neutral with regard to jurisdictional claims in published maps and institutional affiliations.

Copyright: (C) 2022 by the authors. Licensee MDPI, Basel, Switzerland. This article is an open access article distributed under the terms and conditions of the Creative Commons Attribution (CC BY) license (https:// creativecommons.org/licenses/by/ $4.0 /)$.

\begin{abstract}
The article is devoted to the legal and economic aspects of Arctic seaport developments, using the example of the Russian Federation and the Northern Dimension (ND) partner countries, namely, Iceland and Norway. The authors consistently reveal all the specific points related to the legal regulation of Russian seaport management (ranging from international legal cooperation to domestic strategies and national legislation), and conduct an assessment of the economic prospects for Arctic port development according to the latest data and trends in the field of logistical flows. They also provide a description of the ND countries' seaport developments, primarily economic, taking into account the global environmental agenda. In conclusion, the authors make their constructive proposals for multilateral cooperation in this area.
\end{abstract}

Keywords: seaport; Arctic; northern dimension; sustainable development; economics; law

\section{Introduction}

The development of inter-country cooperation in the field of seaport logistics (not only for economic, but also for research purposes) $[1,2]$ and infrastructure has long been on the agenda [3] of most international organizations of a regional nature that are directly connected to the Arctic and the main transport routes in this region. This includes, for example, cooperation within the Barents Euro-Arctic Transport Area (BEATA), which regularly reviews and updates its Joint Barents Transport Plan [4]. In particular, this plan notes the existence of a number of large joint international projects, including the Northern Dimension Partnership on Transport and Logistics (NDPTL). The NDPTL adopted the Memorandum of Understanding that sets out the modalities of establishing the Northern Dimension Partnership on Transport and Logistics, and which outlines the framework for multilateral cooperation in all key areas of logistics [5]. The 2019 BEATA plan also highlights the importance of ensuring the sustainability of maritime transport, citing an IMO decision that has set two targets to cut emissions by 2050. Logistics in the Arctic should be implemented taking into account the most modern approaches and technologies in order to ensure the unconditional reliability of each technological process with an acceptable minimum level of environmental damage [6], that is, they should fully comply with the principle of sustainable development and a "precautionary approach". The note by the United Nations Conference on Trade (UNCTAD) secretariat called "Climate change adaptation for seaports in supports of the 2030 Agenda for Sustainable Development" says: "[...] due to the opening up of new Arctic shipping routes, there will be significant 
engineering challenges due to the projected increases in extreme sea levels and coastal erosion along Arctic coastlines and thawing permafrost.

In addition, extreme winds and waves can cause coastal erosion, port and coastal defence overtopping and flooding, infrastructure failures and operational disruptions" [3].

Special attention at the UN level is paid to the issue of seaports' energy efficiency (with the maximum reduction of electric energy consumption), as well as the "decarbonisation of the shipping sector". This attention follows from the need to prevent deglaciation, as well as from a significant change in the fragile ecosystem of the Arctic region.

Thus, the global agenda has a direct impact on the development of seaport hubs, which have a significant influence on the level of gross regional product. At the same time, industry makes a significant contribution to the indicators of international port development as a territory, that is, any manufacturing enterprises located within the administrative boundaries of specific ports [7], which, in turn, has an impact on the environment in the seaport water area.

The content of the article conceptually reflects the theoretical and practical foundations of research that have developed in science concerning maritime logistics, intermodal transportation and the network development of cross-border supply support [8].

The main problem and goal of the study is to review the legal, economic and political foundations for the development of seaports in the Russian Arctic, including their comparison with the seaports of Northern Dimension countries (Norway and Iceland, which are leaders in the innovation rating [9]), with a brief analysis of port infrastructure and development strategies.

The relevance of the issue is in the analysis of the best practices that can be applied in the countries participating in regional cooperation, including the formation of an effective concept for the development of Russian ports, taking into account the structure of the economy and the challenges of entering the global market for transit and the supply of goods.

The article consists of an introduction, a methodology section, five paragraphs containing subparagraphs, and a conclusion.

The research questions are reflected in the title of the paragraphs, which are NSR Seaports: General Information; Legal and Regulatory Framework of the NSR Ports' Activities; Infrastructure Projects; Russian Port Infrastructure Development Strategy; Arctic Seaports of Europe.

\section{Methodology}

The research article is based on general scientific methods (analysis, synthesis, induction and deduction), as well as specialized methodology (comparative legal method, formal legal method, method of legal hermeneutics, system method, structural-functional method) which is adopted in the framework of legal and political science. A significant place in the article is given to the formal legal approach, with an analysis of the Russian legal system for seaport management. Additionally, a description of Russia's bilateral relations with two key Arctic European partners-Iceland and Norway-is given.

\section{NSR Seaports: General Information}

According to data from the website of the Universal Marine Company "Arctic" (U.M.C.A.), in total, more than 70 trans-shipment bases and ports are located along the Northern Sea Route. The main points of the Northern Sea Route are the ports located in Murmansk, Arkhangelsk, Igarka, Dudinka, Tiksi, Pevek, etc. Vessels equipped in Murmansk and Arkhangelsk set off eastward, calling at Dikson, Dudinka, and Igarka in the Yenisei Gulf region. After the Laptev Sea, ships move on to Nordvik and Tiksi, near the Kolyma River, and to Ambarchik, and the route ends in Pevek and Providence Bay.

The NSR's peculiarity is its short navigation: it takes $2-4$ months or more to navigate it when using nuclear icebreakers to overcome ice massifs. Despite this nuance, the Northern 
Sea Route is recognized as a profitable alternative to the southern routes. The advantages of cargo transportation between the NSR ports are presented in Table 1 [10].

Table 1. The advantages of the Northern Sea Route.

\begin{tabular}{cc}
\hline Advantages & Description \\
\hline Minimum distance & $\begin{array}{c}\text { When moving from Murmansk to Yokohama, vessels } \\
\text { travel 12,840 nautical miles through the Suez Canal, and } \\
5770 \text { nautical miles along the Northern Sea Route. }\end{array}$ \\
\hline Economy of time and fuel & $\begin{array}{c}\text { Freight costs are reduced, and } \\
\text { ships do not have to wait in line. }\end{array}$ \\
\hline Safety & Cargo transportation on the Suez Canal carries the risk \\
of Somali pirate attacks.
\end{tabular}

According to the research institute Nordregio and the automatic identification system, all NSR ports and harbors belong to the territories that depend on the ice situation, while most of the Norwegian and Icelandic ports are ice-free. According to the Order of the Ministry of Transport of Russia No. 373 of 4 December 2013, "On approval of the lists of seaports included in the respective seaport administrations" (with amendments as of 17 June 2019), four seaports are directly located on the NSR coast:

(1) Dickson;

(2) Dudinka;

(3) Pevek;

(4) Tiksi [11].

The Federal Agency for Maritime and River Transport (Rosmorrechflot) lists [12] the Western Arctic ports:

(1) Murmansk;

(2) Arkhangelsk;

(3) Kandalaksha;

(4) Vitino;

(5) Onega;

(6) Mezen;

(7) Varandey;

(8) Naryan-Mar;

(9) Sabetta;

(10) Dudinka;

(11) Dickson;

(12) Khatanga [13].

The site also lists the ports of the Primorsky Krai and the Eastern Arctic:

(1) Vladivostok;

(2) Vostochny;

(3) Nakhodka;

(4) Zarubino;

(5) Olga;

(6) Posyet;

(7) Tiksi;

(8) Anadyr;

(9) Pevek;

(10) Providence Bay;

(11) Egvekinot;

(12) Beringovsky [14]. 


\section{Legal and Regulatory Framework of the NSR Ports' Activities}

The main legislative act "regulating legal relations of merchant shipping in Russian seaports, establishing the procedure for the creation, opening, closing of seaports, for carrying out activities, including the provision of services, as well as establishing the basis for state regulation of activities in seaports" is the Federal Law of 8 November 2007 No. 261-FZ "On seaports in the Russian Federation and on amendments to certain legislative acts of the Russian Federation" (Federal Law "On Seaports") [15]. Part 3 of Article 1 of the Federal Law "On Seaports" states that "seaports are understood as seaports in the same meaning as they are defined in the Merchant Shipping Code of the Russian Federation". Part 1 of Article 9 of the Merchant Shipping Code of the Russian Federation (RF MSC) states that "a seaport means its territory and a set of seaport infrastructure facilities located within the boundaries of this territory, used to carry out activities for merchant shipping, including the provision of services" [16]. Part 3 of the same article determines that activities in seaports are carried out in accordance with Federal Law (in this case, the previously mentioned Federal Law "On seaports").

The Federal Law "On Seaports" consists of seven chapters and forty-one articles. The chapter titles correspond to the described key issues (see Table 2).

Table 2. The structure of the Federal Law "On Seaports".

\begin{tabular}{cc}
\hline Chapter & Article \\
\hline Chapter 1. General provisions & Articles 1-5 \\
\hline Chapter 2. Establishment, opening and closing of the seaport & Articles 6-7 \\
\hline $\begin{array}{c}\text { Chapter 3. State regulation of activities in the seaport } \\
\text { Chapter 4. Basics of providing services in the seaport. } \\
\text { Prices (tariffs, rates) for services in the seaport }\end{array}$ & Articles 8-16_1 \\
\hline $\begin{array}{c}\text { Chapter 5. Features of the provision of services for } \\
\text { transshipment of goods in the seaport }\end{array}$ & Articles 20-27 \\
\hline Chapter 6. Land and property relations in the seaport & Articles 28-31 \\
\hline Chapter 7. Final Provisions & Articles 32-41 \\
\hline
\end{tabular}

According to Part 3 of Article 2 of the Federal Law "On Seaports", it is established that "if an international treaty of the Russian Federation establishes rules other than those provided for by this Federal Law, the rules of the international treaty are applied". This article corresponds to Part 4 of Article 15 of the Constitution of Russia. At the same time, Part 4 of Article 2 additionally establishes that "decisions of interstate bodies adopted on the basis of the provisions of international treaties of the Russian Federation in their interpretation, contrary to the Constitution of the Russian Federation, are not subject to execution in the Russian Federation. Such a contradiction can be established in the manner determined by the Federal Constitutional Law". This article again corresponds to Part 6 of Article 125 of the Constitution, which says that "international treaties of the Russian Federation that do not comply with the Constitution of the Russian Federation are not subject to entry into force and application".

According to Article 6 of the Federal Law "On seaports", a seaport is created on the basis of the RF territorial planning scheme in the field of federal transport development (railway, air, sea transport, inland waterways, pipeline transport) and federal highways, and by a decision of the Government of Russia. The Russian government has approved a $\mathrm{RF}$ territorial planning scheme in the field of federal transport (railway, air, sea transport, inland waterway transport) and federal highways (as amended on 9 April 2021) [17].

According to this scheme, Paragraph 4 "Seaports" provides for "[...] an increase in the throughput of seaports and in their efficiency in coordination with the creation of a logistics system, including both port terminals for various purposes and terminals in major transport hubs of the country, including dry ports". This paragraph lists 34 seaports of 
Russia, and the subsection "As part of the NSR development and the infrastructure of Arctic ports" named three ports:

(1) Dickson seaport (Krasnoyarsk Krai, Dickson District);

(2) Tiksi seaport (Republic of Sakha (Yakutia), Bulunsky District);

(3) Seaport of Pevek (Chukotka Autonomous Okrug, Chuanchunsky District).

As you can see, this list does not include the port of Dudinka mentioned earlier.

The five main goals of the modernization of berths and port facilities are presented in Figure 1.

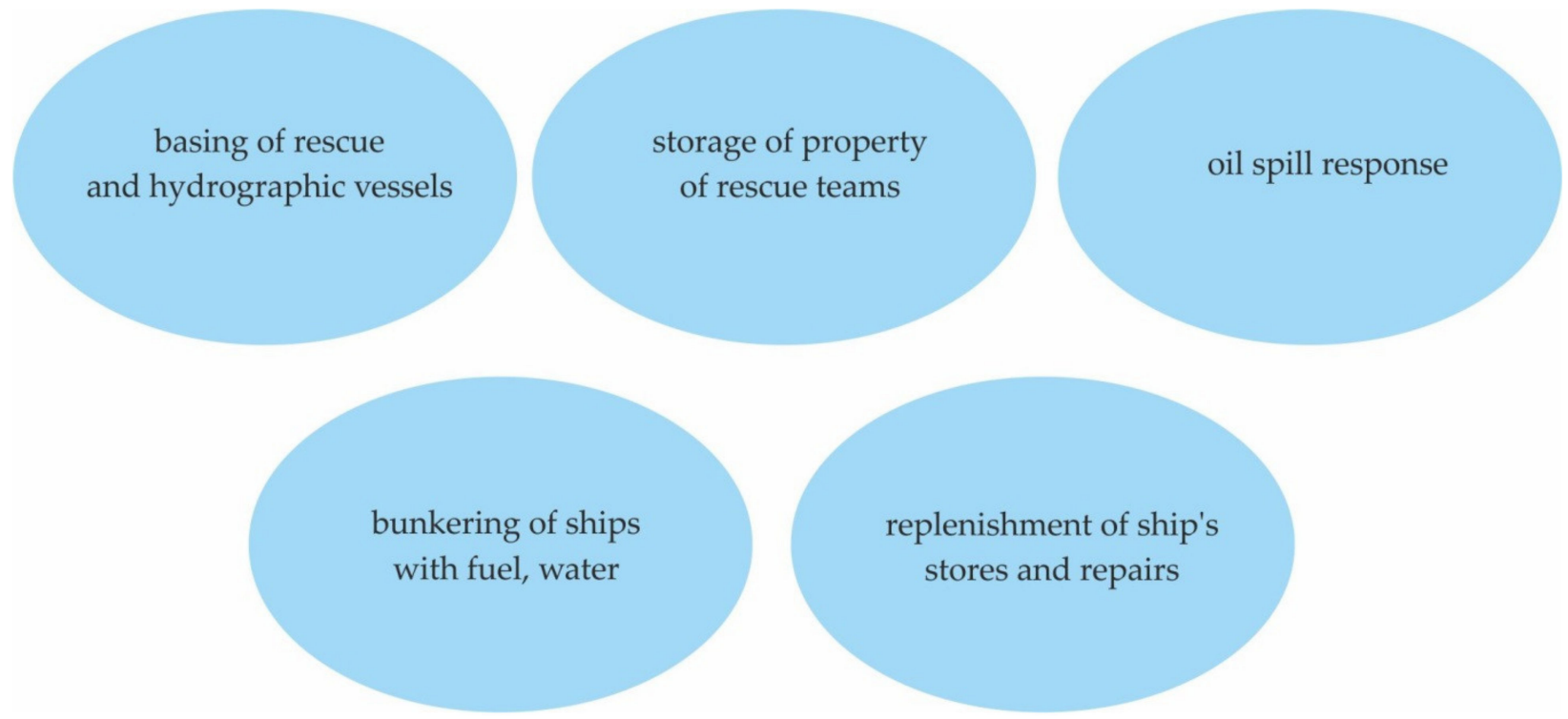

Figure 1. The goals of modernization of berths and port facilities in Russia.

With regard to the construction and modernization of the infrastructure of a number of river ports (inland water transport), it is noted that this construction "provides access to the Northern Sea Route, which is a promising international transport corridor. The construction of the ports will ensure a more efficient transfer of goods from sea transport to inland water transport and vice versa". These river ports are as follows:

(1) Pokrovka, Zeya, Svobodny (Amur Oblast);

(2) Osetrovo (Irkutsk Oblast);

(3) Olekminsk, Lenek, Belogorsk (Republic of Sakha (Yakutia)).

The need for the ports' development with the construction of trans-shipment complexes in the mouths of the Lena, Yana, Indigirka and Kolyma Rivers is also noted.

In the NSR water area, there is a regulatory approval system for the navigation of vessels. On 15 March 2013, the Administration of the Northern Sea Route was created to organize the navigation of ships in the NSR water area. Its functions in the area are:

The acceptance of applications for obtaining a permit for the navigation of vessels in the NSR water area, the consideration of such applications and the issuance of permits for the navigation of vessels in this water area;

The issuance of certificates to persons carrying out ice pilotage giving them the right to conduct such pilotage in the NSR water area;

The monitoring of hydrometeorological, ice and navigational conditions in the NSR water area;

The coordination of the installation of aids to navigation and areas of hydrographic work in this water area;

Providing assistance in organizing search and rescue operations in the NSR water area;

Providing assistance in carrying out operations to eliminate the consequences of pollution from ships with hazardous and noxious substances, sewage or garbage; 
The provision of information services (in relation to the NSR water area) in the field of navigation, outlining requirements for ensuring the safety of navigation, providing hydrographical and hydrometeorological support for navigation and ensuring the implementation of icebreaker assistance;

Providing recommendations for the development of navigation routes and the use of icebreaking vessels in the NSR water area, taking into account the hydrometeorological, ice and navigational conditions in this water area, etc. [18].

\section{Infrastructure Projects}

According to the official website of Rosmorrechflot, as a result of the federal project "Seaports of Russia", executed within the framework of the transport part of the comprehensive plan for the modernization and expansion of the main infrastructure for the period up to 2024, the capacity gain of Russian ports will be 330 million tons. Financing for the development of maritime transport infrastructure in 2019-2024 will amount to RUB 817.4 billion, including federal budget funds of RUB 125 billion and off-budget financing of RUB 692.4 billion.

The implementation of 39 measures for the development of port infrastructure and 10 measures in the field of shipbuilding is planned. Within the framework of the Arctic Basin, the Russian Government has set tasks in the following areas:

(1) The seaport of Murmansk:

The reconstruction of the facilities in the third cargo area. The main participants are Rosmorport and Eurochem. Terms of implementation: 2017-2021. Increase in design capacity: 1.5 million tons;

The construction of an offshore LNG transshipment complex in the Murmansk Oblast. The main participants are Novatek-Zapadnaya Arctic and Rosmorport. Terms of implementation: 2018-2023. Increase in design capacity: 20.87 million tons;

The planning of investment projects for Murmansk Commercial Sea Port. The main participants are Murmansk Commercial Sea Port and Rosmorport. Terms of implementation: 2017-2024. Increase in design capacity: 2.5 million tons;

The planning of a marine specialized trans-shipment complex for bulk cargo in the seaport of Murmansk. The main participants are Sea Terminal Tuloma and Rosmorport. Terms of implementation: 2019-2023. Increase in design capacity: 6 million tons.

(2) The seaport of Arkhangelsk:

The construction of a mining and processing plant based on the Pavlovskoye leadzinc ore deposit (Novaya Zemlya). The main participants are First Mining Company and Rosmorport. Terms of implementation: 2019-2022. Increase in design capacity: 0.36 million tons.

(3) The seaport of Pevek:

The reconstruction of federal property objects in the seaport of Pevek, Chukotka Autonomous Okrug. The main participant is Rosmorport. Terms of implementation: 2017-2020. Increase in design capacity: 0.8 million tons [19].

A special place is occupied by the issue of determining long-term tariffs for NSR users: "The Government of the Russian Federation together with the State Atomic Energy Corporation Rosatom shall consider the issues of establishing long-term tariffs for icebreaking escort of vessels in the Northern Sea Route water area and rates of port dues levied in seaports located on the coast of this water area, taking into account the mandatory maintenance of good condition and development of transport and port infrastructure facilities, ensuring the safety of navigation, maintaining the balance of interests of suppliers and consumers of services, and, if necessary, submit appropriate proposals" (V.V. Putin) [20].

A critical assessment of the infrastructure project developments in Russia shows the need for a clearer answer to the question of derived demand, which is associated with the demand for a good or service because of one's ability to acquire or produce another good or 
service. Derived demand can be caused by the means required to complete the production of a particular good, including capital, land, labor and non-essential raw materials. In these cases, the demand for raw materials is directly related to the demand for products that require raw materials to produce. In economics, there is the concept of "Dutch disease". The Dutch disease phenomenon occurs when a national economy produces and exports one commodity, or a particular sector becomes a booming sector. The increase in exports of certain goods and the expenditure of accumulated income from minerals strengthens the national currency, reducing competitiveness and, consequently, the volume of production or exports in non-prosperous sectors [21].

In this case, in relation to Russia, we are talking about the excessive influence of the oil and gas sector, which provokes this disease, including in the Arctic. A similar situation, for example, exists in one of Russia's foreign trade partners, the Republic of Azerbaijan. Like Russia, this country is rich in oil and gas, which naturally actualizes the existence of the Dutch disease syndrome [22].

As experts from the Higher School of Economics of Russia noted a few years ago, "Subsidizing the economy through low domestic prices, the outflow of human capital and at the same time the influx of unskilled labor, active nationalization in the economy and an increase in the state's share in GDP are all symptoms of the Dutch disease. And all these symptoms are present in Russia" [23]. Moreover, the Arctic occupies one of the first places in terms of these symptoms [24], including due to the loss of the unique ethno-cultural composition of the region against the backdrop of negative migration processes [25,26], as well as the lack of a well-coordinated system for improving the quality of education in local communities [27].

To prevent the symptoms of this disease in Russia, it is necessary to develop a hightech economy, as Governor of the Krasnoyarsk Krai Aleksandr Uss said in December 2020: "There is the reason to believe that the next generations will have a budget that is mainly filled by our oil producing enterprises. But at the same time, I would like not to meet the so-called Dutch syndrome, or Dutch disease, in the Krasnoyarsk Krai, when there is an orientation towards income from oil workers. We need to develop small and medium-sized businesses, ensure investment in the service sector, consumer demand, and so on [... ]. As part of the large-scale project Vostok Oil, a modern terminal Port Bay Sever will be created in the region. It will become the largest logistics hub that will provide synergy between the river and the sea, and will give impetus to the development of Arctic transport routes. The necessary documents for the construction of the terminal are already prepared. In addition, it is planned to build 50 vessels of various types, including oil tankers and supply vessels. It is expected that the new Russian icebreaker Arktika will come to work in the test mode for ice trials in Dudinka. Importantly, the infrastructure for shipping needs will appear along the Yenisei, as well as three new airports. A road network will be constructed in the north of the region." [28].

Unfortunately, as a number of experts note, there are also problems with recruiting highly qualified specialists in the above industry:

1. Executive authorities on the subject of the Arctic zone have no system for monitoring the long-term need for specialists in the leading economic sectors of the Arctic zone.

2. Forecast data of sectoral and corporate personnel services are not available. Currently, it is a difficult task solve. Its relevance may be due to the poorly formed internal need for forecasts of the current and, especially, long-term demands for labor resources, which, in turn, may be due to a decrease in the intensity (and cessation in some areas) of the geological exploration of the land and shelf of the Arctic Ocean, a significant time lag from exploration to the beginning of development of mineral deposits (over 20 years) and, thus, a significant period of awaiting a return on investment and, as a consequence, weak interest on the part of resource corporations.

3. The labor markets in the subjects of the Arctic zone of the Russian Federation are characterized by an imbalance between the demand (10,536 specialists in the framework of the medium-term need) and supply (61,424 students in universities in the region) of 
labor resources. In order to reduce the imbalance in the shortage of engineering personnel and an overabundance of specialists in the field of management and services, the Ministry of Education and Science of the Russian Federation (from May 2018, the Ministry of Science and Higher Education) reduces the target number of admissions to universities in the region in the training programs Administration and Management, and increases the target admissions for technical (engineering) and the natural science fields of training. [29] Additionally, as a serious drawback, it is worth mentioning a lack of investment in the cluster development of the Arctic and the low innovative activity of businesses in parts of the Russian Arctic [30].

\section{Russian Port Infrastructure Development Strategy}

According to the official website of Rosmorport, "the development of port facilities in the Russian Federation is carried out within the framework of the Rosmorport's draft The strategy for the development of the seaport infrastructure of Russia until 2030 [31], developed in accordance with the order of the Ministry of Transport of Russia of 30 July 2010, No. 167, and approved by the Maritime Board under the Government of the Russian Federation; it is performed through the implementation of various investment projects aimed at the reconstruction of existing port infrastructures and the construction of new sea terminals. will be:

In the period up to 2030, the main directions for the development of port facilities

The accelerated development of terminals of paramount importance (container and coal);

The development of port hubs on the main sea basins of the country;

The elimination of imbalances in the development of railway and road access routes to seaports [32].

The Strategy also notes that, "according to the plans for the Arctic development, it is planned to radically modernize the Northern Sea Route and increase its cargo turnover by 2020 to 30-35 million tons annually through transportation from new offshore facilities and transit flows from Europe to the countries of the Asia-Pacific region [... ].

To implement plans for the development of the Arctic shelf and the delivery of hydrocarbons to Europe and the USA, as well as the use of the NSR for transit traffic between the countries of North-Western Europe and the Asia-Pacific region (Japan, China, USA, Canada), it is planned to develop the infrastructure for the NSR navigation safety. It is planned to radically update the icebreaker fleet, build specialized ice-class and reinforced ice-class vessels, double-hulled tankers with additional emergency supplies".

\section{International Projects of Rosmorport}

According to the official website, Rosmorport, as the largest company and the backbone of the port business, actively cooperates with international transport organizations and financial institutions, associations and foreign companies. Over the years, there has been an exchange of experience in the field of port management, cruise shipping, navigation safety in seaports, pilotage, icebreaker assistance, the construction of port infrastructure and sea terminals and environmental protection [33].

As noted, the main direction of cooperation with the EU countries is associated with the north-west Baltic direction: "In the course of the development of international cooperation to ensure the navigation safety, the North-Western Basin Branch of Rosmorport, which ensures the functioning of the Russian national server, takes an active part in the joint project of an interstate monitoring system for marine vessels in the Baltic Sea based on the AIS HELCOM AIS EWG automatic identification system. Denmark, Estonia, Finland, Germany, Latvia, Lithuania, Poland, Russia, Sweden, Norway are taking part in the project. [... ] Within the framework of the marine group meeting, a wide list of topical issues was considered:

prevention of pollution of the marine environment as a result of shipping activities in the Baltic Sea; 
prevention of waste water discharges from ships;

ensuring the operation of port reception facilities for handling ship-generated waste; preventing the transfer of unwanted aquatic organisms with ship ballast water; preventing air pollution from ships, as well as enhancing the navigation safety" [34].

As for the Arctic, according to the report "Development of seaports at the intersection of international trade routes (2nd Edition)", prepared by $\mathrm{RwC}$, "the development of the Arctic port infrastructure is mainly driven by oil and gas production. A year after the commissioning of the first stage of the Yamal LNG project in 2017 by a joint venture between the Russian Novatek, the French concern TOTAL and the Chinese National Oil and Gas Corporation and the Silk Road Fund, shipments have doubled. In 2018, exports of LNG, gas condensate, oil and petroleum products accounted for almost $90 \%$ of the total supply, or 17 million tons. In 2019, Novatek announced that China National Petroleum Corporation and China National Offshore Petroleum Corporation are also investing in a second Arctic LNG project with an annual capacity of about 2 million tons. In addition to investments, seven Chinese enterprises took part in the production of modular structures for the Yamal project. COSCO Shipping Energy Transportation Co., Ltd., a subsidiary of China's COSCO Shipping, together with Mitsui O.S.K. Lines, Ltd. participates in the investment, construction and operation of ARC7 ice-class LNG tankers specially designed for the Yamal project.

In 2018, transit traffic accounted for less than $1 \%$ of traffic. In the past, the volume of transit through the Northern Sea Route was about 200-300 thousand tons per year. Maersk and COSCO made several test passes through the NSR. In 2019, the development of the Northern Sea Route project was added to the Russian plan for the modernization and expansion of infrastructure with a budget of over RUB 580 billion ( $\$ 9.5$ billion) for the next 5 years. The plan includes expanding the capacity of roads to ports in the Western and Eastern Arctic basins. The planned target throughput will be 20 thousand units of vehicles per day. An important component of the plan for the Arctic Ocean basin is the development of the icebreaker fleet. It is planned to replace 8 and build 4 new icebreakers operating on liquefied natural gas" [34].

\section{Arctic Seaports of Europe}

\subsection{Iceland}

The main Arctic seaport is Akureyri. According to the Cruise Iceland portal, the following seaports and terminals are distinguished:

(1) Port of Akranes;

(2) Port of Akureyri;

(3) Port of Djúpivogur;

(4) Port of Eskifjörður;

(5) Port of Grímsey;

(6) Port of Grundarfjörður;

(7) Port of Hafnarfjörður;

(8) Port of Hrísey;

(9) Port of Húsavík;

(10) Port of Ísafjörður;

(11) Port of Raufarhöfn;

(12) Port of Reykjanes;

(13) Port of Reykjavík;

(14) Port of Sauðárkrókur;

(15) Port of Seyðisfjörður;

(16) Port of Siglufjörður;

(17) Port of Stykkishólmur;

(18) Port of Skagaströnd;

(19) Port of Vestmannaeyjar;

(20) Port of Vesturbyggð; 


\section{(21) Port of Porlákshöfn [35]}

Portal Searates.com allocates slightly more ports, namely, 26 [36]. The port of Akureyri is the second largest port after Reykjavik. In recent years, the port has become a favorite port of call for cruise ships, and thousands of tourists come here every year. It has 13 berths. According to The Fishing Daily portal, "the Icelandic fishing port, Akureyri is set to move to a greener future as it looks to become the first harbor in the country to implement electrification and reduce greenhouse gas emissions and noise pollution.

Gudmundur Ingi Gudbrandsson, Minister for the Environment and Natural Resources, and Petur Olafsson, Port Authority of Akureyri, signed an agreement on the Government's investment in the port's electrification of ISK 43.8 million ( $€ 290,000)$. The project involves setting up a high-voltage connection for cargo ships, fishing vessels and smaller cruise ships at Tangabryggja, but construction is already underway. With the electricity connection, greenhouse gas emissions are reduced from ships in Akureyri harbour, which can then connect electricity to land instead of burning oil. At the same time, noise pollution from ships and electrical stations on board is reduced.

Energy exchanges and climate issues are closely linked and energy exchanges are a key component of Iceland's climate action plan. Energy exchanges are being carried out in various areas in accordance with a resolution passed by the Parliament, which was approved in 2017. These include projects related to energy exchanges at sea and in the fisheries and energy infrastructure related to them.

Thórdís Kolbrún Reykfjörð Gylfadóttir, Minister of Tourism, Industry and Innovation: "Energy exchanges, including in ports and ocean-related activities, are among our most important environmental and climate issues and also important economic issues in the long term. I therefore particularly welcome this agreement today, which is in line with the policy we have marketed. We have been making remarkable progress in land-based energy exchanges, are second in the world in the automation of the automotive fleet, and now it is time to move forward with energy exchanges in maritime-related operations".

Guðmundur Ingi Guðbrandsson, Minister of the Environment and Natural Resources: "We need to work on changes in all areas of society so that Iceland can reduce greenhouse gas emissions and contribute to reducing climate change. Port exchanges are major and important steps in that direction".

The Minister for the Environment and Natural Resources, in collaboration with the Minister of Tourism, Industry and Innovation, has allocated grants for electrification of ports in nine other locations in the country this year to reduce greenhouse gas emissions" [37].

Additionally, one cannot fail to mention the promising project of the deep-water seaport, the Finnafjord Port (Icelandic: Finnafjörður), the construction time of which was announced to be in the period from 2021 to 2023.

In 2013, the Icelandic engineering firm EFLA and Bremenports $\mathrm{GmbH}$, which operates the ports of Bremen in Germany, announced that they would be investigating the viability of an Arctic trans-shipment hub at Finnafjord.

In 2019, Bremenports $\mathrm{GmbH}$ announced that it had entered into a joint venture agreement with EFLA to build the port. Bremenports $\mathrm{GmbH}$ currently owns $66 \%$ of the port, EFLA owns $26 \%$ and the nearby municipalities of Vopnafjardarhreppur and Langanesbigg own $8 \%$. EFLA says the port could become a distribution center for offshore oil and minerals in Greenland and Iceland.

In the report "An Arctic Dream-The Opening of the Northern Sea Route: impact and possibilities for Iceland", Sigurður Almar Ómarsson notes that, in the context of the development of Icelandic seaports, the priority should be the development of transit hubs, as well as working in a tourism direction, seeing as Iceland is one of the few countries with an impeccable reputation for sustainable environmental management [38]. Lassi Heininen also points out the importance of Iceland's role as a transit hub for container shipping in his article "State of the Arctic Strategies and Policies-A Summary" [39]. 
For several years, Iceland and Russia have been trying to establish long-term relations in the field of maritime logistics and shipbuilding, despite the foreign policy crisis in relations between Russia and Europe as a whole.

Back in October 2019, Iceland announced that it was exploring the possibility of building a large international port in the northeast of the island, which could be integrated into the structure of the Northern Sea Route and benefit from this project. According to the TASS agency, Icelandic companies engaged in the development of ship design and engineering and the production of high-tech fish processing equipment are considering opportunities to participate in the modernization of the Russian Far East fishing fleet and coastal processing, carried out as part of the investment quota distribution program [40].

As of 30 June 2021, St. Petersburg and Iceland are expanding cooperation in shipbuilding and Arctic development.

The Governor of St. Petersburg Aleksandr Beglov noted that a fishing trawler for the Norebo company is being built at the Severnaya Verf and under the supervision of the Icelandic bureau Nautik. This will be the ninth trawler built at the St. Petersburg shipyards in cooperation with Iceland. Currently, new programs are being developed until 2027. Aleksandr Beglov stressed that St. Petersburg and Iceland should use the opportunity to expand their dialogue within the framework of the "Interreg. Northern periphery and the Arctic" program [41].

Earlier in February 2021, the Russian Government approved the "Action Plan of the Concept of Cross-Border Cooperation in Russia", developed by the Ministry of Economic Development. The document contains measures for the development of the regulatory and legal framework for cross-border cooperation and interaction in the trade, economic, agro-industrial, cultural, migration and law enforcement spheres on the entire border of the Russian Federation. An important part of the plan was the activities aimed at the development of program documents for cooperation with neighboring countries. In particular, in accordance with the plan, a new generation of programs of cross-border cooperation between Russia and the EU countries will be developed for the next period of 2021-2027, as well as the issue of Russia joining the aforementioned program, "Interreg. Northern periphery and the Arctic" [42].

\subsection{Norway}

A whole series of Arctic seaports operate in Norway. Two of them can be characterized as an example: Hammerfest and Honningsvag.

\subsubsection{Hammerfest Seaport}

Hammerfest is a Norwegian port and naval base (floating base). It is located in a sheltered bay on the northwestern coast of Kvaløya Island. The port of Hammerfest is one of the main hubs in the communications system of Northern Norway, providing up to $30 \%$ of sea freight traffic in the North of the country. The Navy's floating base can provide the basing, material and technical supply and minor repairs of ships, including destroyers.

There are three entrance fairways to the port of Hammerfest with a depth of up to $18 \mathrm{~m}$. Anchorages with a depth of 9 to $32 \mathrm{~m}$ ensure the simultaneous accommodation of 12 large-tonnage vessels. The length of the waterfront is more than $1.5 \mathrm{~km}$ with a depth of more than $9 \mathrm{~m}$. The total turnover of sea cargo transportation of the port is over 4 million tons. The Hammerfest ferry crossing is connected (through the Kvalsunnet Strait) with the state road that runs along the coast of Norway.

\subsubsection{Honningsvag Seaport}

There are five berths in the port, all of which are located within a 5 min walk from the city center. Sometimes larger cruise ships are anchored, and passengers are transported to the piers via ships' boats.

Honningsvag is one of the ferry ports on the express route; the Norwegian government subsidizes the Norwegian Coastal Express. This is a regular service for the transport of 
passengers and goods in Norway. The ferry cruise route runs between two ports with an interchange: Bergen (extreme south) and Kirkenes (extreme north). It connects 34 ports, which include the Norwegian communities with no roads or air access [43].

There are also other ports in Norway, in particular the seaport of Kirkenes [44]; Vardø seaport [45]; Tromsø seaport [46].

In the development of seaports, Norway relies on "green technologies"; this is confirmed by the Government's action plan for green shipping [47], Maritime OpportunitiesBlue Growth for a Green Future: The Government's Maritime Strategy [48].

Within the framework of its strategic documents, Norway, as well as Iceland, prioritizes the development of "green ports", which are primarily associated with the development of the port infrastructure for receiving ships powered by hydrogen and biogas, including a focus on navigation safety, a preferential taxation system for ship owners, actively using electricity to support navigation, etc.

The development of projects for electric ship creation deserves special attention. As of June 2021, the construction of the world's first high-speed electric ferry has begun in Norway: "The TrAM (Transport-Advanced and Modular) project partners for modular, zero-emission fast passenger vessels have announced the start of construction of the world's first all-electric ferry at the Fjellstrand shipyard on the west coast of Norway. [... ] The TrAM project consortium brings together 13 European partners and is coordinated by the Norwegian city council of Rogaland through the Norwegian independent transport company Kolumbus, which will also own and operate the demonstration vessel. The catamaran is designed and will be built with a Wärtsilä power system and a Servogear propulsion system at the Norwegian shipyard Fjellstrand. The modules for the ship will be supplied by Leirvik (Norway) and the aluminum will be supplied by the Norwegian company Hydro Extrusion Norway. The Danish company Fraunhofer will be responsible for the use of modular technologies used in the automotive and aviation industries for the shipbuilding industry, as well as for the integration of the Smart City platform" [49].

At the same time, it should be noted that seaports are often used for military purposes. In particular, the gradual militarization of the seaport of Tromsø, which essentially has a dual purpose, like the port of Vardø, is of particular concern in the socio-political circles of Russia: “[... ] In November 2020, Norwegian Defense Minister Frank Bakke-Jensen gave an official opinion on the "advantages" for his country from the admission of American nuclear submarines to the port of Tønsnes in the city of Tromsø. And in February 2021, the US European Command announced the deployment of American B-1B Lancer bombers in Norway [... ].

There is also the naval base Bodø and a fishing port in the Rönvik Bay. The length of the Bodø waterfront is $1.7 \mathrm{~km}$ with depths of up to $12.6 \mathrm{~m}$. The port has long been chosen by the American military. After all, navigation in Bodø is year-round, it can provide the basing of any ships from corvettes to destroyers.

The headquarters of the commanders of Air Force and Navy of the NATO allied forces located in Northern Norway is on the territory of the port of Bodø; and an airfield with a concrete runway of $2800 \mathrm{~m}$ and underground shelters for fighters designed to control the airspace and water area of the Norwegian Sea is deployed $2 \mathrm{~km}$ south-west. But the main thing is the sea routes connecting the Atlantic and Arctic oceans" [50].

Such military strategic activity in Norway on the borders of Russia, obviously, is reflected in the economic level of bilateral interactions. Back in August 2019, the officials of Oslo, represented by Norwegian Foreign Minister Ine Marie Eriksen Søreide, stated that the Norwegian side is looking closely at the Northern Sea Route, but does not yet see the economic prospects of the route: "So far, the route operates within the framework of existing agreements. But it should be checked for compliance with environmental standards that are put forward for ship routes in the Arctic. As far as I can see, the NSR has serious problems in relation to everything: from search and rescue operations and insufficient infrastructure along the entire route to an extremely harsh climate. This greatly 
complicates the task of making this route profitable and commercially successful, as many would like" [51].

Additionally, according to the Izvestia newspaper, "[... ] Norway did not consider the possibility of providing the ports of Svalbard for use within the NSR. Earlier, Russian experts assumed that the ports of the island, convenient in terms of location, could be used for the Northern Sea Route".

On the other hand, the Russian embassy noted that the problem of shipping to Spitsbergen also now remains outside the NSR, since the route passes within the boundaries of Russian territorial waters [52].

\section{Conclusions}

The main research problem was to review the legal and economic and political foundations for the development of seaports in the Russian Arctic, including their comparison with the seaports of Northern Dimension partners (Norway and Iceland), with a brief analysis of port infrastructure and development strategies. The analysis showed the need for systematic utilization of the symptoms of the "Dutch disease" in the structure of the Russian economy, as well as the priority development of high-tech port infrastructure, which will give impetus to the creation of thousands of new jobs and help overcome the symptoms characteristic of the disease.

The proposals within the Northern Dimension partnership are as follows:

A joint interstate strategy for the development of Arctic seaports, based on the most advanced national practices that relate to the navigation safety and the environment;

A focus on "green technologies" in Arctic seaport management (autonomous ships [36], electric ships, nuclear energy and liquid gas), as well as the modernization of container ships, which creates conditions for a ship to be able to transport a much larger number of containers, which are subsequently to be served by container ports [53];

The digitalization of port infrastructure, including the stability of transportation (online platforms, conference calls (video and audio), the exchange and remote monitoring of data to ensure the continued functioning of supply chains) during a pandemic, which has created great problems for cargo traffic in recent a few years [54];

The creation of an international consortium to attract international shipping companies to create a sustainable system of trans-shipment transit ports within the framework of the Northern Dimension partnership in order to develop the Arctic ports of partner countries;

The exchange of best practices in the development of port technological infrastructure, including the joint training of specialists of a given profile;

The prevention of rejection of "inter-port competition" [55].

Author Contributions: Conceptualization, M.Y.Z. and N.M.K.; methodology, N.M.K. and M.Y.K.; validation, M.Y.K.; investigation, M.Y.Z. and K.S.Z.; data curation, N.M.K.; writing—original draft preparation, M.Y.Z.; writing—review and editing, M.Y.Z. and K.S.Z.; project administration, K.S.Z. All authors have read and agreed to the published version of the manuscript.

Funding: This article is part of a project funded by EC DG NEAR under a grant agreement ENI/2017/387-477 "Development of a Think Tank Functions of the Northern Dimension Institute".

Institutional Review Board Statement: Not applicable.

Informed Consent Statement: Not applicable.

Data Availability Statement: The data presented in this study are available on request from the corresponding author.

Conflicts of Interest: The authors declare no conflict of interest. 


\section{References}

1. Avdonina, N.S.; Kudryashova, E.; Zaikov, K.S. Terrae Novae: The Tenth Scientific and Educational Expedition 'Arctic Floating University'. Polar J. 2019, 9, 473-475. [CrossRef]

2. Zaykov, K.S.; Kalinina, M.R.; Tamitskiy, A.M.; Saburov, A.A.; Shepelev, E.A. Scientific and Educational Space of the Arctic: Norway. Arct. North 2016, 23, 144-170. [CrossRef]

3. Avdonina, N.S.; Tamitskiy, A.M.; Zaikov, K.S. The Seventh International Forum: "The Arctic: Present and Future: Perspectives and Actions". Polar J. 2018, 8, 213-215. [CrossRef]

4. Joint Barents Transport Plan. Revised Draft. Main Report 2019. Available online: https://www.barentsinfo.fi/beac/docs/JBTP2 019_MAIN_REPORT_190910.pdf (accessed on 1 December 2021).

5. Memorandum of Understanding Setting out the Modalities of Establishing the Northern Dimension Partnership on Transport and Logistics. Available online: https://eeas.europa.eu/archives/docs/north_dim/docs/mou_ndptl_en.pdf (accessed on 11 November 2021).

6. Lipina, S.A.; Zaikov, K.S.; Lipina, S.V. Introduction of Innovation Technology as a Factor in Environmental Modernization in Russian Arctic. Econ. Soc. Chang. Facts Trends Forecast 2017, 10, 164-180. [CrossRef]

7. Kudryashova, E.V.; Lipina, S.A.; Zaikov, K.S.; Bocharova, L.K.; Lipina, A.V.; Kuprikov, M.; Kuprikov, N.M. Arctic zone of the Russian Federation: Development problems and new management philosophy. Polar J. 2019, 9, 445-458. [CrossRef]

8. Zaikov, K.S.; Kalinina, M.R.; Kondratov, N.A.; Tamitskiy, A.M. Innovation Course of Economic Development in the Northern and Arctic Territories in Russia and in the Nordic Countries. Econ. Soc. Chang. Facts Trends Forecast 2017, 10, 59-77. [CrossRef]

9. Climate Change Adaptation for Seaports in Support of the 2030 Agenda for Sustainable Development. UNCTAD.org. Available online: https:/ / unctad.org/system/files/official-document/cimem7d23_en.pdf (accessed on 11 November 2021).

10. Gapochka, A.A. International Sea Ports Hubs as a Factor in the Development of the Baltic Sea Region. Ph.D. Thesis, St. Petersburg State University, Saint Petersburg, Russia, 2017; 177p. Available online: https://disser.spbu.ru/files/disser2/disser/ 1WXZVyzNrc.pdf (accessed on 11 November 2021).

11. Universal Marine Company “Arctic” (U.M.C.A.). Ports of the Northern Sea Route. Available online: https://umcashipping.ru/ article/porty-severnogo-morskogo-puti/ (accessed on 12 November 2021).

12. Order of the Ministry of Transport of Russia of 4 December 2013 No. 373 “On Approval of the Lists of Seaports Included in the Respective Seaport Administrations". Available online: https://docs.cntd.ru/document/499073383?section=text (accessed on 11 November 2021).

13. Ports of the Western Arctic. Available online: http://morflot.gov.ru/deyatelnost/napravleniya_deyatelnosti/portyi_rf/reestr_ $\mathrm{mp} /$ portyi_zapadnoy_arktiki.html (accessed on 12 November 2021).

14. Ports of Primorsky Krai and Eastern Arctic. Available online: http://morflot.gov.ru/deyatelnost/napravleniya_deyatelnosti/ portyi_rf/reestr_mp/portyi_primorskogo_kraya_i_vostochnoy_arktiki.html (accessed on 15 November 2021).

15. Federal Law of 8 November 2007 No. 261-FZ “On Seaports in the Russian Federation and on Amendments to Certain Legislative Acts of the Russian Federation" (as Amended on 11 June 2021). Available online: http:/ / docs.cntd.ru/document/902070928 (accessed on 15 November 2021).

16. Merchant Shipping Code of the Russian Federation (as amended on 11 June 2021). Available online: http://docs.cntd.ru/ document/901732423 (accessed on 15 November 2021).

17. Order of the Government of the Russian Federation of 19 March 2013 No. 384-r "On Approval of the Territorial Planning Scheme of the Russian Federation in the Field of Federal Transport (Railway, Air, Sea, Inland Waterway) and Federal Highways" (revised from 23 June 2021). Available online: https://docs.cntd.ru/document/499009611? marker=6540IN (accessed on 17 November 2021).

18. Bobrova, Y.V. The Northern Sea Route: National Legal Regime in a Changing International Context (Analytical Note); RIAC: Moscow, Russia, 2016; Available online: https:/ / russiancouncil.ru/upload/NorthernSeaRoute-Policybrief9-ru.pdf (accessed on 17 November 2021).

19. List of Investment Projects. Available online: https://www.rosmorport.ru/investors/innovations/investlist/ (accessed on 15 November 2021).

20. Vladimir Putin Instructed to Work out the Issue of Long-Term Tariffs for Pilotage of Ships along the Northern Sea Route. Available online: https:/ / portnews.ru/news/311478/ (accessed on 17 November 2021).

21. Sadik-Zada, E.R. Distributional Bargaining and the Speed of Structural Change in the Petroleum Exporting Labor Surplus Economies. Eur. J. Dev. Res. 2020, 32, 51-98. [CrossRef]

22. Niftiyev, I. Dutch Disease Effects in the Azerbaijan Economy: Results of Multivariate Linear Ordinary Least Squares (OLS) Estimations. HSE Econ. J. 2021, 25, 309-346. [CrossRef]

23. Selivanova, M.O. Stradaet li Rossiya «gollandskoy bolezn'yu» [Does Russia suffer from Dutch disease?]. Available online: https:/ /iq.hse.ru/news/177670885.html (accessed on 30 December 2021).

24. Khoreva, O.; Konchakov, R.; Leonard, C.S.; Tamitskiy, A.; Zaikov, K. Attracting skilled labour to the North: Migration loss and policy implications across Russia's diverse Arctic regions. Polar Record 2018, 54, 324-338. [CrossRef]

25. Zaykov, K.S.; Maksimov, A.M.; Tamitskiy, A.M.; Troshina, T.I. Ethnosocial Situation in Arctic Regions of Russia and the State National Policy. Polis 2018, 2, 57-67. [CrossRef] 
26. Zaikov, K.S.; Katorin, I.V.; Tamitskii, A.M. Migration Attitudes of the Students Enrolled in Arctic-Focused Higher Education Programs. Econ. Soc. Chang. Facts Trends Forecast 2018, 11, 230-247. [CrossRef]

27. Zaikov, K.; Tamitskiy, A.; Zadorin, M. Legal and political framework of the federal and regional legislation on national ethnic policy in the Russian Arctic. Polar J. 2017, 7, 125-142. [CrossRef]

28. Uss, A. Razvivat' Neftyanuyu Otrasl', ne Zarabotav Gollandskuyu Bolezn' [To develop the oil industry without earning Dutch disease]. Available online: https:/ / tass.ru/interviews/10350833 (accessed on 30 December 2021).

29. Zaikov, K.S.; Kondratov, N.A.; Kudryashova, E.V.; Tamitskii, A.M. The need for workforce in constituent entities of the Arctic zone of the Russian Federation. Econ. Soc. Chang. Facts Trends Forecast 2018, 11, 184-201. [CrossRef]

30. Gorokhov, A.M.; Zaikov, K.S.; Kondratov, N.A.; Kuprikov, M.Y.; Kuprikov, N.M.; Tamickij, A.M. Analysis of Scientific and Educational Space of the Arctic Zone of the Russian Federation and its Contribution to Social and Economic Development. Eur. J. Contemp. Educ. 2018, 7, 485-497. [CrossRef]

31. Rosmorport. Strategy for the Development of the Seaport Infrastructure of Russia until 2030. Available online: https: / www rosmorport.ru/media/File/State-Private_Partnership/strategy_2030.pdf (accessed on 20 November 2021).

32. Rosmorport. Strategy for the Development of the Seaport Infrastructure of Russia. Available online: https://www.rosmorport. $\mathrm{ru}$ /investors/seastrategy (accessed on 20 November 2021).

33. Rosmorport. International Cooperation. Available online: https://www.rosmorport.ru/investors/inv_international (accessed on 20 November 2021).

34. Development of Seaports at the Crossroads of International Trade Routes, 2nd ed. St. Petersburg, Russia. 2020. Available online: https:/ / www.pwc.ru/ru/publications/razvitiye-morskikh-portov-v2.html (accessed on 22 November 2021).

35. Ports of Cruise Iceland. Available online: https://www.cruiseiceland.com/ports-of-iceland (accessed on 23 November 2021).

36. Iceland Ports. Available online: https://www.searates.com/ru/maritime/iceland.html (accessed on 23 November 2021).

37. Icelandic Fishing Port Akureyri Moves towards Greener Future. The Fishing Daily, 14 June 2020. Available online: https: //thefishingdaily.com/latest-news/icelandic-fishing-port-akureyri-moves-towards-greener-future/ (accessed on 23 November 2021).

38. Ómarsson, S.A. An Arctic Dream-The Opening of the Northern Sea Route: Impact and Possibilities for Iceland. Bachelor's Thesis, Bifröst University, Bifröst, Iceland, 2010. Available online: https:/ /skemman.is/bitstream/1946/6099/1/An\%20Arctic\%20 Dream_The \%20Opening\%20of\%20the\%20Northern\%20Sea\%20Route_impact\%20and\%20possibilities\%20for\%20Iceland.pdf (accessed on 22 November 2021).

39. Heininen, L. State of the Arctic Strategies and Policies-A Summary. Available online: https://arcticyearbook.com/images/ yearbook/2012/Scholarly_Papers/1.Heininen.pdf (accessed on 24 November 2021).

40. TASS. Iceland is Showing Interest in the Port Construction for the Northern Sea Route. Available online: https://tass.ru/ ekonomika/ 6967020 (accessed on 24 November 2021).

41. St. Petersburg and Iceland are Expanding Cooperation in Shipbuilding and the Arctic Development. Available online: https: // portnews.ru/news/315014 (accessed on 26 November 2021).

42. The Government of the Russian Federation Approved an Action Plan for the Concept of Cross-Border Cooperation in Russia. Available online: https://economy.gov.ru/material/news/pravitelstvo_rf_utverdilo_plan_meropriyatiy_po_realizacii_ koncepcii_prigranichnogo_sotrudnichestva_v_rossii.html (accessed on 26 November 2021).

43. Honningsvag (Mageroya Island, Norway). Available online: https://www.cruisemapper.com/ports/honningsvag-port-203 (accessed on 26 November 2021).

44. Kirkenes (Norway). Available online: https://www.searates.com/ru/port/kirkenes_no.htm (accessed on 28 November 2021).

45. Vardo (Norway). Available online: https://www.searates.com/ru/port/vardo_no.htm (accessed on 1 December 2021).

46. Tromso (Norway). Available online: https://www.searates.com/ru/port/tromso_no.htm (accessed on 1 December 2021).

47. The Government's Action Plan for Green Shipping. Available online: https://www.regjeringen.no/contentassets/2ccd2f4e14d4 4bc88c93ac4effe78b2f/the-governments-action-plan-for-green-shipping.pdf (accessed on 1 December 2021).

48. Maritime Opportunities_-Blue Growth for a Green Future. The Government's Maritime Strategy. Available online: https: / / www.regjeringen.no/contentassets / 05c0e04689cf4fc895398bf8814ab04c/maritim_strategi_engelsk_trykk.pdf (accessed on 1 December 2021).

49. Construction of the World's First High-Speed Electric Ferry Has Begun in Norway. Available online: https:/ / portnews.ru/news / 314148/ (accessed on 1 December 2021).

50. Ports of Norway on Pentagon Maps. Available online: https://zen.yandex.ru/media/id/5dc69465c7891f51f5fb5143/portynorvegii-na-kartah-pentagona-60ab3c69288764247f23790b (accessed on 1 December 2021).

51. Absolutely: Russia will Develop the Northern Sea Route without the Participation of Norway. Available online: https://iz.ru/91 2535/elnar-bainazarov / bezoslovno-rossiia-budet-osvaivat-sevmorput-bez-uchastiia-norvegii (accessed on 1 December 2021).

52. Karachev, D.V. Legal Features of Innovative Technologies Testing in the Russian Federation. Challenges and Opportunities for the Maritime Industry through Experiments with Maritime Autonomous Surface Ships. Mar. Law Insur. 2021, 1, 67-76. Available online: https: / / marinelaw.ru/wp-content/uploads/MPiS/\%D0\%9C\%D0\%BE\%D1\%80\%D1\%81\%D0\%BA\%D0\%BE\%D0\%B5

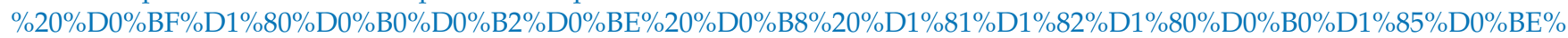
D0\%B2\%D0\%B0\%D0\%BD \%D0\%B8\%D0\%B5\%20\%E2\%84\%961.pdf (accessed on 21 December 2021). 
53. Prospects for the Development of Seaports. Available online: http:/ /www.morvesti.ru/analitika/1688/89829/ (accessed on 21 December 2021).

54. Gutsulyak, V.N. Legal Regime of the Sea Ports in the Light of the Global Pandemic COVID-19. Mar. Law Insur. 2021, 1, 6-25. Available online: https:/ / ui-miit.ru/files/docs/morskoe_pravo_i_strahovanie/mpis_1.pdf (accessed on 21 December 2021).

55. Zajkov, K.S. The "Arctic competition" problem and the marine transport hubs: Is it a clash of business interests or the knockout game? Arct. North 2015, 19, 31-47. [CrossRef] 